\title{
Transviando cidades:
}

\author{
o relatar a si mesmo e a
}

\section{construção de uma memória queer no}

\author{
curta-metragem Virgindade
}

ISSN: 2350-0844

n. II, v. 2 mai. -out. 2019 р. $83-102$.

\author{
Henrique Rodrigues Marques ${ }^{1}$
}

RESUMO: Graças aos avanços e a popularização dos meios de captação audiovisual que aconteceram nas últimas décadas, a produção de documentários em primeira pessoa apresentou lato crescimento nos últimos anos. Por seu caráter egocêntrico centrado na vida pessoal de seus realizadores, esse tipo de filme é constantemente alvo de acusações e deslegitimação. Mas não pode o relato em primeira pessoa transcender a experiência individual? Seriam esses filmes necessariamente narcisistas e supérfluos? Falar de si mesmo é político? Partindo de algumas reflexões sobre o filme-ensaio e o documentário em primeira pessoa, esse artigo se propõe a fazer uma análise do curta-metragem brasileiro Virgindade (Chico Lacerda, 2015). Pretende-se assim apontar como o uso estrutural da obra fílmica produz um discurso que constrói uma certa memória utópica queer, como proposta por José Esteban Muñoz.

PALAVRAS-CHAVE: cinema queer; filme-ensaio; memória; política.

\begin{abstract}
Thanks to the improvements and popularization of the new medias of audiovisual recording that happened in the last few decades, the production of first-person documentaries displayed a great boost over the last years. By virtue of it self-centered nature, focusing in the private life of the filmmakers, this kind of film is an unswerving target of accusations and devaluation. But cannot the first-person narration to surpass the individual experience? Are these films necessarily narcissistics and superfluous? Talk about oneself is political? Based on some theories about the essay film and the first-person documentary, this essay proposes to make an analysis of the Brazilian short film Virgindade (Chico Lacerda, 2015). The aim is to point out how the structural use of the filmic work creates a discourse that builds a certain queer utopian memory, as proposed by José Esteban Muñoz.

Keywords: queer cinema; essay film; memory; politics.
\end{abstract}

Resumen: Debido a los avanzos y a la popularización de los medios de captación audiovisual que ocurrieron en las últimas décadas, la producción de documentales en primera persona presentó un amplio crecimiento en los últimos años. Por su carácter egocéntrico centrado en la vida personal de sus realizadores, este tipo de película es constantemente objetivo de acusación y deslegitimación. ¿Pero no puede el relato en primera persona trascender la experiencia individual? ¿Serían estas películas necesariamente narcisistas y superfluas? ¿Hablar de si mismo no es político? Partiendo de algunas reflexiones sobre la película-ensayo y el documental en primera persona, este artículo se propone a analizar el corto metraje brasilero Virgindade (Chico Lacerda, 2015). Así se pretende apontar como el uso estructural de la obra fílmica produce un discurso que construye una cierta memoria utópica queer, como propuesto por José Esteban Muñoz.

Palabras clave: cine queer; película-ensayo; memoria; política.

${ }^{1}$ Mestrado no Programa de Pós-Graduação em Multimeios do Instituto de Artes da Universidade Estadual de Campinas (UNICAMP). E-mail: henrique.rodriguesm@ hotmail.com 


\section{Introdução}

Como pode se notar já pelo título de um dos principais livros sobre o assunto, o filme-ensaio não é exatamente um fenômeno recente dentro da história do cinema. Timothy Corrigan, em $O$ filmeensaio: desde Montaigne e depois de Marker (publicado originalmente em 2011), volta nas origens literárias para iniciar suas indagações sobre o campo do ensaístico, citando o escritor Michel de Montaigne (1533-1592) como um possível precursor da prática em sua versão escrita, ao passo que institui Carta da Sibéria (1957), do cineasta Chris Marker, como um dos primeiros filmes a se caracterizar como tal. Já Laura Rascaroli, em How the essay film thinks (2017), nota que desde os anos 1920 é possível encontrar filmes que possam ser considerados ensaísticos, a depender do que está sendo considerado como definição do termo - questão que, como afirma a autora, segue sendo um terreno de disputa teórica. Uma acepção possível, como ponto de partida para o debate, é a de que

A característica mais comumente destacada do ensaístico é o ponto pessoal ou subjetivo que organiza as suas observações e reflexões, uma posição estrutural cuja atividade do autoquestionamento, creio, é uma das chaves para entender o distinto poder e complexidade do ensaio. (CORRIGAN, 2015, p. 81)

Embora a noção de filme-ensaio exista, de maneira consolidada, desde pelo menos a segunda metade do século XX, é inegável que sua prática (e veiculação) se popularizou excepcionalmente dentro das últimas décadas, culminando na sua presença massiva na atualidade, como aponta Rascaroli ao dizer que vivemos em um tempo em que o filme-ensaio encontra sua fase de maior riqueza e expansão. Com a chegada do vídeo, nos anos 1970, das câmeras caseiras nos anos 1980 e do advento do digital à partir dos anos 1990, tornou-se cada vez mais comum cineastas que adotam o viés confessionário do modelo ensaístico para compor suas obras. Atualmente, são diversas as terminologias usadas para falar desse cinema em que o cineasta volta a câmera para si mesmo ou, pelo menos, assume um posicionamento, uma voz ativa dentro da narrativa. Além de filme-ensaio, essas produções têm sido definidas em termos como documentário em primeira pessoa, etnografia familiar, filme autobiográfico ou cinema dispositivo, para citar alguns. Todas essas categorias não configuram necessariamente oposições, assim como não são sinônimos. Um filme pode ser ao mesmo tempo ensaístico e uma etnografia familiar, por exemplo, enquanto uma outra obra pode ser lida como exemplar de tudo que citamos. Essas nomenclaturas oferecem suporte para diferentes reflexões teóricas que partem de objetos bastante similares. Sendo assim, são categorias que se permeiam, contaminam e interseccionam constantemente, compartilhando características, linguagens, estéticas.

Periódicus, Salvador, n.11, v. 2, mai-out.2019 - Revista de estudos indisciplinares em gêneros e sexualidades Publicação periódica vinculada ao Núcleo de Pesquisa NuCuS, da Universidade Federal da Bahia - UFBA ISSN: 2358-0844 - Endereço: http://www.portalseer.ufba.br/index.php/revistaperiodicus 
Levando em consideração que nosso objetivo neste artigo não é o de estabelecer categorias ou definir domínios, optamos por trabalhar, ao mesmo tempo, com autores que utilizam o conceito de filme-ensaio e outros que preferem a definição filme em primeira pessoa. Partindo de um filme facilmente localizado em ambas categorias, acreditamos que seja mais profícuo à nossa reflexão manter em aberto esse campo, sem ceder a definições rígidas e estanques. Ao eleger como objeto de estudo o curta-metragem Virgindade (Chico Lacerda, 2015), nossa ambição não é encerrá-lo dentro de um determinado gênero, mas sim pensar suas potências políticas enquanto uma obra artística que assume um discurso em primeira pessoa.

\section{O pessoal é político: aproximações entre o filme-ensaio e o cinema queer}

Assim como o filme-ensaio - e, por conseguinte, o filme em primeira pessoa - já possui uma longa trajetória dentro da história do cinema, a categoria também não é novidade no âmbito do cinema queer. Na reedição do livro New queer cinema: the director's cut, B. Ruby Rich (2013) fala sobre os diversos fatores que permitiram que, dentro do governo conservador de Ronald Reagan e da crise da AIDS, diversos cineastas gays e lésbicas nos Estados Unidos pudessem produzir filmes tão transgressores. Uma das razões elencadas pela autora é o surgimento da câmera de vídeo camcorder em meados dos anos 1980. Nas palavras de Rich (2013, p. xvii), "as recém-criadas camcorders possibilitaram a fácil produção de mídia eletrônica no âmbito pessoal pela primeira vez na História." [nossa tradução] $]^{2}$ Aliado a isso, a década de 1980 foi marcada pelo surgimento tanto da televisão a cabo (que permitiu a formação de canais municipais, nos quais filmes poderiam ser exibidos em nível local), quanto dos aparelhos de videocassete (que "revolucionaram a distribuição"). Sendo assim, essa geração de jovens cineastas se viu liberta das tiranias da indústria cinematográfica institucional que, seguindo os valores da época, tentaria censurar ou nem sequer produziria os seus filmes. "Ontem, como hoje, as mudanças tecnológicas podem levar a transformação social e política também.” [nossa tradução] $^{3}$ (RICH, 2013, p. xvii)

Enquanto isso, Rascaroli reconhece o papel que o desenvolvimento contínuo das novas tecnologias exerceram na história do filme-ensaio, sempre encarado como “o filme do amanhã”, já que “tal desenvolvimento é necessário para atualizar o sonho da câmera que se torna cada vez mais flexível, portátil, sempre pronta para ser usada, e responsiva ao pensamento humano - assim como uma caneta.”

\footnotetext{
${ }^{2}$ Do original: "Newly invented camcorders enabled easy production of electronic media at the personal level for the first time in history"

${ }^{3}$ Do original: "Then as now, technological changes could lead to social and political transformation too."
}

Periódicus, Salvador, n.11, v. 2, mai-out.2019 - Revista de estudos indisciplinares em gêneros e sexualidades Publicação periódica vinculada ao Núcleo de Pesquisa NuCuS, da Universidade Federal da Bahia - UFBA ISSN: 2358-0844 - Endereço: http://www.portalseer.ufba.br/index.php/revistaperiodicus 
[nossa tradução] $]^{4}$ (RASCAROLI, 2017, p. 4) Sendo assim, tanto o cinema queer quanto o filme-ensaio, embora já existissem, só puderam se consolidar dentro da história do cinema graças as tecnologias de captação de imagem que democratizaram o acesso aos meios de produção audiovisual.

No entanto, os pontos de congruência entre esses dois campos não se encerram aí. Na continuação de seu argumento, Rascaroli defende que o desenvolvimento dessa produção cada vez mais pessoal não pode ser desassociada de um sentido político, pois "a possibilidade de se fazer um cinema menos condicionado a formas comerciais de significação e a sistemas industriais de financiamento e produção, tem claras implicações políticas." [nossa tradução] ${ }^{5}$ (RASCAROLI, 2017, p. 5) Na fala de Rascaroli, fica evidente mais uma das relações entre o cinema queer e o filme-ensaio. Nos moldes do lema “o pessoal é político” (popularizado pelos movimentos de liberação gay e feminista durante a década de 1970), a teórica sugere que essa produção audiovisual de caráter idiossincrásico é automaticamente de inclinação política, já que assumir o "eu” é assumir também responsabilidade. Não obstante, a autora estreita ainda mais esses laços ao afirmar que

\begin{abstract}
o ensaio se mantém no âmago da não-ficção crítica que é produzida por opositores, póscoloniais, acentuados, exilados, feministas, lésbicas, gays, bissexuais, transgêneros, sujeitos queer, dentre outros, precisamente porque é a materialização mais direta do sonho de um cinema de expressões críticas e pessoais, desonerado das amarras da produção sistemática, e mais adequado a escapar do controle de todas as formas de censura. [nossa tradução] ${ }^{6}($ RASCAROLI, 2017, p. 5)
\end{abstract}

Não por acaso, não é difícil listar filmes do cinema queer, de diversas nacionalidades, que se encaixem na definição de filme-ensaio e/ou documentário em primeira pessoa: Silverlake life: the view from here (Tom Joslin e Peter Friedman, 1993), Blue (Derek Jarman, 1993), Tongues untied (Marlon Riggs, 1994), Family name (Macky Alston, 1997), Tarnation (Jonathan Caouette, 2003), Post card to daddy (Michael Stock, 2010), The prep school negro (Andre Robert Lee, 2012), E agora? Lembra-me (Joaquim Pinto, 2013), Uncle howard (Aaron Brookner, 2016), Small talk (Hui-Chen Huang, 2016), Strong island (Yance Ford, 2017), só para ficar nos longa-metragens. No entanto, vale ressaltar ainda a

\footnotetext{
${ }^{4}$ Do original: "such development is needed to actualize the dream of a camera that becomes increasingly flexible, portable, always ready to be used, and responsive to human thought - just like a pen."

${ }^{5}$ Do original: "The possibility of making a cinema less conditioned by mainstream forms of signification and industrial systems of financing and production has obvious political implications."

${ }^{6}$ Do original: "the essay has continued to be at the core of critical nonfiction produced by oppositional, postcolonial, accented, exiled, feminist, and lesbian, gay, bisexual, transgender, and queer subjects, among others, precisely because it is the most direct embodiment of the dream of a cinema of personal and critical expression, unencumbered by the constraints of systemic production, and better suited to escape the control of all forms of censorship."
}

Periódicus, Salvador, n.11, v. 2, mai-out.2019 - Revista de estudos indisciplinares em gêneros e sexualidades Publicação periódica vinculada ao Núcleo de Pesquisa NuCuS, da Universidade Federal da Bahia - UFBA ISSN: 2358-0844 - Endereço: http://www.portalseer.ufba.br/index.php/revistaperiodicus 
produção de artistas queer que, dentro do curta-metragem, do cinema experimental e até mesmo da videoarte, dedicaram suas carreiras à produção de filmes em primeira pessoa, utilizando-se do estilo por diversas vezes. Dentre eles, podemos citar nomes como Barbara Hammer, Su Friedrich, Richard Fung, Jan Oxenberg, George Kuchar e Michelle Citron.

No panorama do cinema queer brasileiro mais recente, encontramos produções como Mauro em Caiena (Leonardo Mouramateus, 2012), Nova Dubai (Gustavo Vinagre, 2014), Inconfissões (Ana Galizia, 2018), Quarto camarim (Camele Queiroz, 2018) e, obviamente, Virgindade (Chico Lacerda, 2015).

\section{O privado é público: a responsabilidade política do relatar a si mesmo}

Não é incomum que, em entrevistas e depoimentos, cineastas gays demonstrem certo descontentamento em serem vistos como cineastas gays. Suponho que Chico Lacerda não é um deles. Junto com André Antônio, Fabio Ramalho e Rodrigo Almeida, Lacerda fundou, em 2012, o coletivo Surto \& Deslumbramento. Residentes da cidade do Recife, no estado de Pernambuco, o grupo assume, em release oficial disponibilizado no site do coletivo, seu apreço por elementos como "o artificialismo, o lúdico, a paródia, o deboche, a viadagem, a pinta, o pop e a cultura de massa"7, indicando sua forte afiliação à cultura queer.

Os filmes do coletivo são feitos de maneira independente e sem hierarquias pré-definidas, permitindo que os quatro membros se revezem nas diversas funções técnicas e estabeleçam parcerias com outros artistas. Atualmente, o Surto \& Deslumbramento conta com sete curta-metragens e um longa-metragem. É importante notar que a maioria desses trabalhos se encontram disponíveis na internet, uma poderosa janela de exibição independente que, assim como o VHS e os canais de televisão municipais, que segundo Rich foram fundamentais para a distribuição de filmes da geração de cineastas das décadas de 1980 e 1990, abriu um sem-número de possibilidades para cineastas e audiências queer no século XXI. A acessibilidade da internet, assim como seu alcance global, permitiu que, mesmo com poucos recursos, criadores do mundo inteiro veiculassem suas produções para um público que não seria atingido em outras plataformas. Se antes uma pessoa jovem e queer precisava ir em festivais de cinema LGBT para consumir obras que dialogavam com suas sensibilidades, agora esse conteúdo pode ser

${ }^{7}$ Disponível em: http://deslumbramento.com/release.pdf. Acesso em: 28 de janeiro de 2019.

Periódicus, Salvador, n.11, v. 2, mai-out.2019 - Revista de estudos indisciplinares em gêneros e sexualidades Publicação periódica vinculada ao Núcleo de Pesquisa NuCuS, da Universidade Federal da Bahia - UFBA ISSN: 2358-0844 - Endereço: http://www.portalseer.ufba.br/index.php/revistaperiodicus 
acessado dentro de sua própria casa, na distância de um clique e em copioso volume.

Apesar dessa estrutura de produção horizontal, e do curta fazer parte da filmografia do coletivo, Virgindade também é um projeto bastante pessoal de Lacerda. Os cargos de roteiro, direção, fotografia, som, narração e montagem são assinados por ele. Mais em primeira pessoa, impossível.

O filme apresenta uma estrutura bastante simples: em enquadramento estático, cada cena filma uma paisagem urbana da cidade de Recife (a fachada de um prédio, um ponto de ônibus, um posto de gasolina) nos dias de hoje, enquanto na banda sonora ouvimos Lacerda confessar alguma memória do seu processo de descoberta sexual. Na cena de abertura, filmando a casa de sua avó, o autor narra sua primeira lembrança de ter sentido tesão, o que, segundo ele, aconteceu por volta dos quatro anos de idade, engatilhada por uma inocente brincadeira com um amigo da família que envolvia um roleplay de super-herói e certo fetiche por luvas (Fig. 1) Em seguida, conta que aos oito anos viu em uma banca de jornal a primeira revista de pornografia gay, e assim vai seguindo seu relato; cada paisagem, uma lembrança. Por volta do meio da projeção, esse relato é interrompido por uma montagem onírica, durando cerca de três minutos, na qual vemos recortes de partes dos corpos nus de diversos homens, enquanto uma música romântica toca ao fundo (Fig. 2). Os corpos desses homens se mantém anônimos, mas as paisagens que habitam sempre são destacadas. Boa parte das cenas nesse segmento também ocupam espaços públicos, outras são em locações internas, mas todas compartilham uma artificialidade composta por objetos coloridos - um lençol branco com flores rosas, um drink de cor azul acompanhado de um caju, quadros de aspecto kitsch (Fig. 3) - e até mesmo lúdicos nos espaços. O momento remete diretamente aos valores listados no release do coletivo, ao mesmo tempo em que representa uma materialização visual do desejo homossexual do narrador. Diferente das imagens do cotidiano apático da cidade, esse trecho é marcado por uma aura paradisíaca e amistosa. 


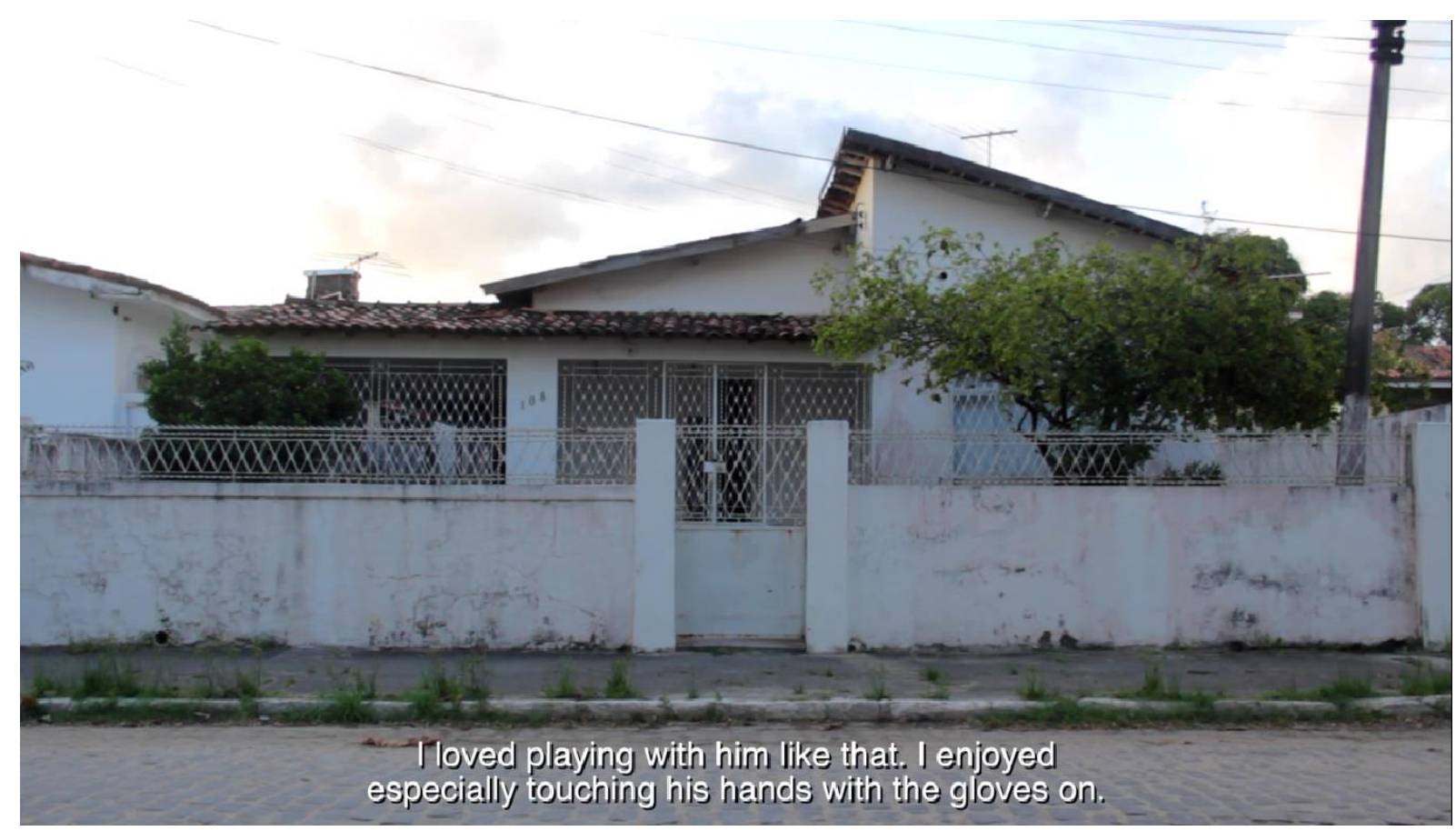

Figura 1 Still do filme "Virgindade" (Chico Lacerda, 2015)

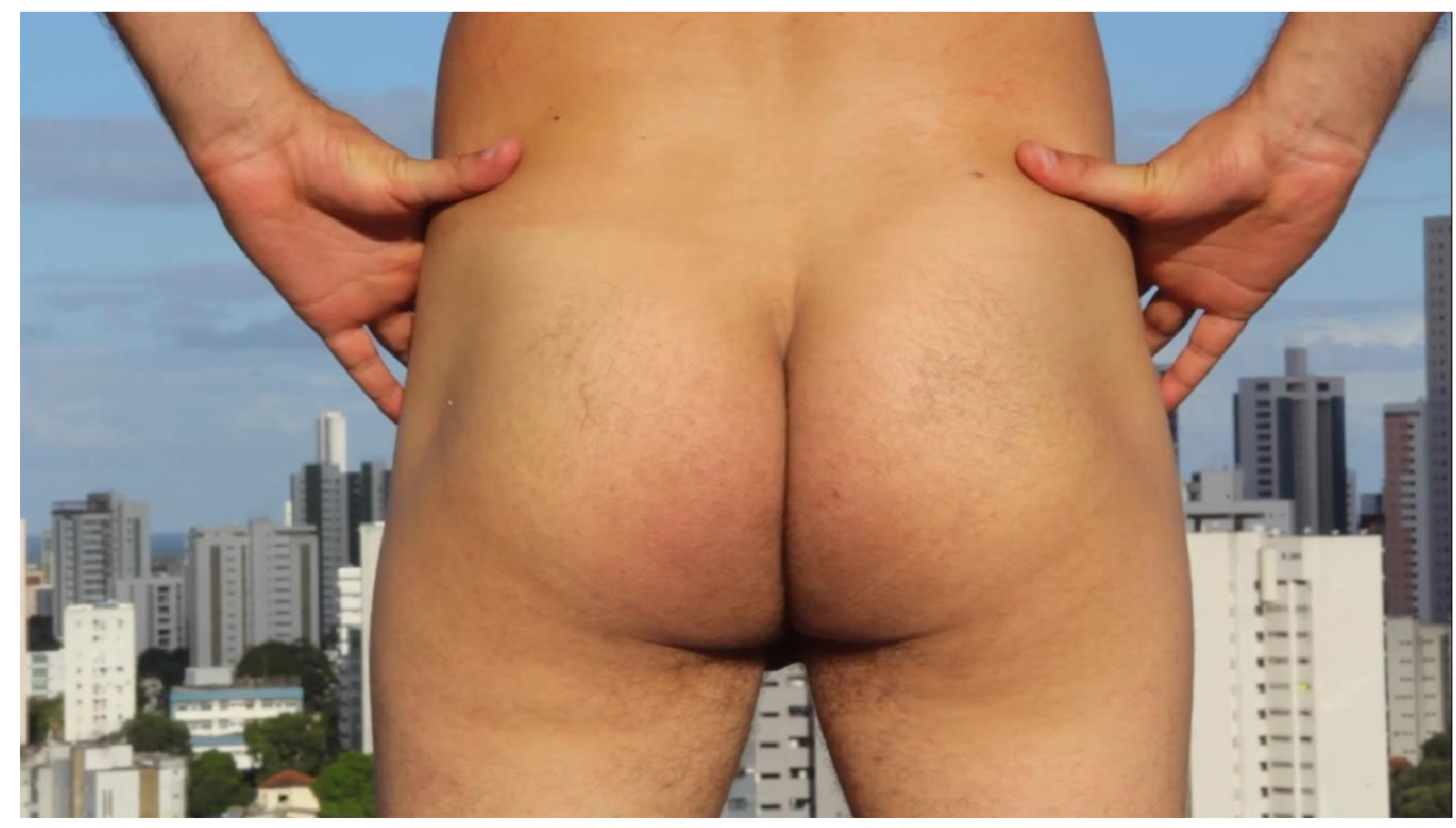

Figura 2 Still do filme "Virgindade" (Chico Lacerda, 2015)

Periódicus, Salvador, n.11, v. 2, mai-out.2019 - Revista de estudos indisciplinares em gêneros e sexualidades Publicação periódica vinculada ao Núcleo de Pesquisa NuCuS, da Universidade Federal da Bahia - UFBA ISSN: 2358-0844 - Endereço: http://www.portalseer.ufba.br/index.php/revistaperiodicus 


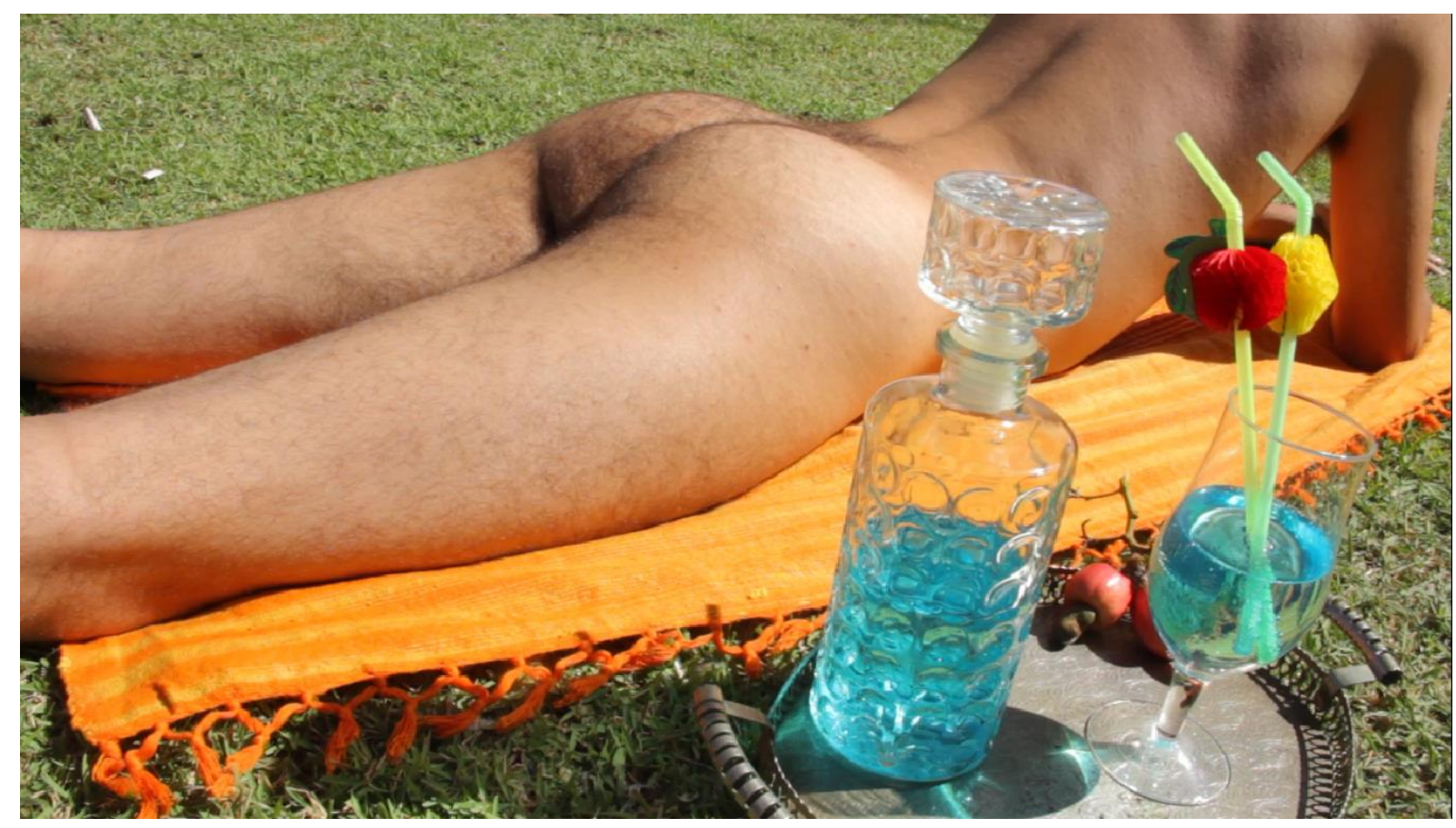

Figura 3 Still do filme "Virgindade" (Chico Lacerda, 2015)

Com exceção dessa digressão ficcional, Lacerda segue um relato de trajetória linear, acompanhando diferentes momentos do seu crescimento, da infância a puberdade, em uma estrutura que remete ao gênero coming of age, relacionando as fantasias sexuais de cada período a uma parte da cidade, embora nunca fique claro onde os espaços mostrados se localizam. Nomes de rua nunca são mostrados, bairros não são mencionados, pontos turísticos e referenciais não estão aparentes. Ao mesmo tempo em que o narrador nos menciona lugares muito específicos da sua história, como a casa de parentes e a escolinha de natação que frequentou, existe um cuidado em manter a imagem em um estado quase genérico. Sem a informação prévia, não sabemos nem que aquela cidade é Recife.

Outro ponto que chama a atenção é a escolha por retratar apenas espaços públicos. Mesmo nas lembranças que remontam a espaços privados, Lacerda opta por filmar a fachada dos prédios, a visão das ruas. Na descrição da experiência de se masturbar lendo as sinopses de filmes pornográficos no "guia de vídeo" (Fig. 4), por exemplo, faria sentido que o cineasta nos mostrasse o lado de dentro da casa onde viveu. Talvez seu quarto onde, posteriormente, ele diz ter escondido o livro para que não descobrissem sua aventura, ou até mesmo a sala de estar, seio do convívio familiar. 


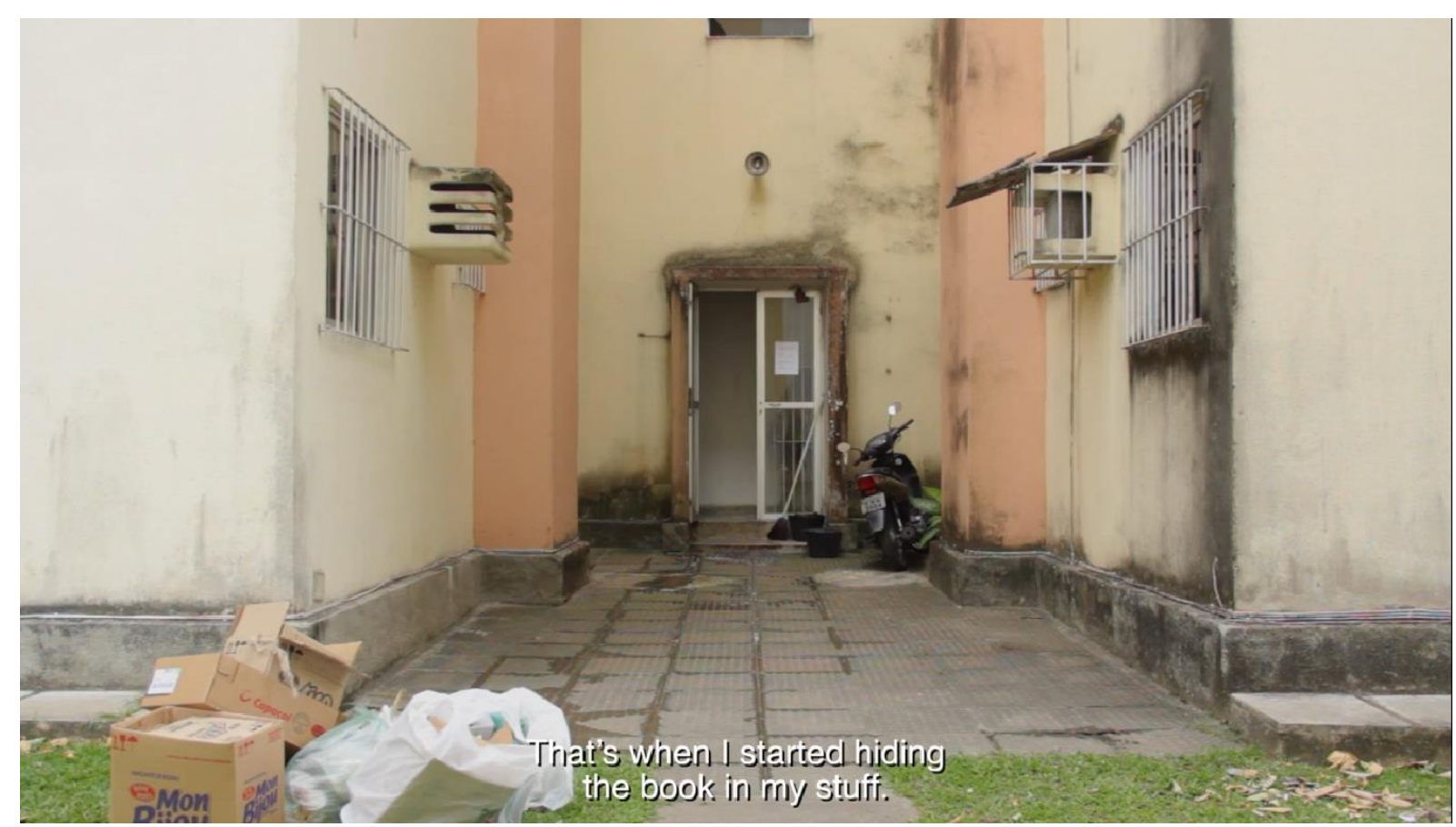

Figura 4 Still de "Virgindade" (Chico Lacerda, 2015)

A escolha do autor, seja ela consciente ou não, de localizar a descoberta do desejo homossexual no âmbito do espaço público é carregada de valores políticos. Historicamente, a sexualidade de pessoas queer sempre se desenvolveu em espaços públicos, longe das vigilâncias da esfera privada (sempre associada ao matrimônio e a família nuclear), seja um banheiro de estação de trem ou um quarto de motel. Embora as intimidades e afetos precisassem existir fora de um regime de visibilidade, em lugares escuros e escondidos, ainda assim essas interações se tornavam possíveis através da apropriação e subversão de locais públicos da cidade. Não por acaso, a questão do sexo em público e as leis que penalizam essas práticas foram pautas centrais no movimento de liberação gay da década de 1970. Ao contrário do que defendiam os conservadores, essas reivindicações não tinham como objetivo a permissividade do sexo em todo lugar e a qualquer momento. Mas, como nota o ativista Pat Califia,

[...] gays e lésbicas não aprenderam sobre leis sexuais o tanto que deviam. A maioria das pessoas que condenam o sexo em lugares públicos parecem não notar que a diferença legal entre sexo público e privado não é tão simples quanto a escolha entre um arbusto e seu quarto. Há muitas nuances entre estes pólos - um quarto de motel, uma sauna, um bar, uma livraria erótica, um carro, um banheiro público, um beco escuro e deserto -, que são territórios disputados, onde a polícia batalha com pervertidos pelo controle. [nossa tradução] ${ }^{8}(2000$, N.P.)

\footnotetext{
${ }^{8}$ Do original: "Gay men and lesbians have not learned so much from the history of sex laws as they should. Most people who condemn public sex do not seem to know that the legal difference between public and private sex is not a simple matter of choosing either the bushes or your bedroom. There are many zones in between - a motel room, a bathhouse, a
} 
Embora as confissões em Virgindade sejam de fantasias sexuais que não se concretizam em atividade sexual propriamente dita, é patente que diversas delas envolvem interações em locais públicos, como quando o protagonista espia a nudez masculina em mictórios e vestiários coletivos, ou na cena final, em que ele flerta com um homem anônimo em um cinema (prática que nós gays conhecemos como cruising). É esse momento inclusive que dá abertura para a frase com que Lacerda encerra o filme: "morri de raiva da minha leseira, de ter perdido a chance de finalmente rolar algo de verdade. Mas aprendi a lição e, a partir daí, comecei a treinar olhos e ouvidos pro maravilhoso mundo da pegação." Com essa afirmação, o "eu" não apenas conclui o seu coming of age narrativo - nessa perda simbólica da virgindade representada pela inocência em não reconhecer um convite sexual implícito -, mas também se filia a uma certa cultura do sexo público: o tal "maravilhoso mundo da pegação" mencionado.

Um dos principais incomôdos da sociedade heterossexual conservadora com as discussões levantadas pela liberação queer gira exatamente em torno de um suposto excesso de exposição pública de práticas que deveriam ficar no âmbito do privado. Não é incomum ouvir de alguém que propaga crimes de ódio contra pessoas LGBT frases como "eu não tenho nada contra, eu só não acho que tem que ficar se mostrando assim, pode ser gay mas dentro de casa, não quero que meu filho veja isso". Esse tipo de afirmação parte da ilusão de que nossas sexualidades (e incluímos aqui também a heterossexual) não são mediadas por relações públicas e, mais do que isso, o equívoco de acreditar que as separações entre público e privado são muito rígidas e bem definidas. Como argumenta Califia, essas duas esferas estão mais próximas do que parece. Em um dos exemplos usados pelo autor, fala-se sobre uma lei, criada em 1967, em que um ato "em público" foi definido como aquele que acontece em qualquer lugar onde estivesse (ou pudesse estar) presente uma terceira pessoa. Sendo assim, pessoas que decidissem explorar práticas sexuais com mais de um parceiro, mesmo que dentro de suas propriedades privadas, poderiam ser penalizadas como infratoras sexuais. Por razões como essa, o autor defende que pessoas queer devem sempre tomar cuidado com as definições dadas a "sexo privado", já que "uma definição muito restrita de privacidade pode nos deixar com pouco ou nenhum direito de ser visivelmente gay, encontrar uns aos outros em lugares públicos, ou participar em sexo fora de relações monogâmicas e fechadas." [nossa tradução] ${ }^{9}$ (CALIFIA, 2000, N.P.)

bar, and adult bookstore, a car, a public toilet, a dark and desert alley - that are contested territory where police battle with perverts for control."

${ }^{9}$ Do original: "Too narrow definition of privacy could leave us with little or no right to be visibly gay, meet each other in public places, or participate in sex outside of monogamous, closeted relationships."

Periódicus, Salvador, n.11, v. 2, mai-out.2019 - Revista de estudos indisciplinares em gêneros e sexualidades Publicação periódica vinculada ao Núcleo de Pesquisa NuCuS, da Universidade Federal da Bahia - UFBA ISSN: 2358-0844 - Endereço: http://www.portalseer.ufba.br/index.php/revistaperiodicus 
A afirmação de Califia descortina também o real discurso que os conservadores proferem contra a visibilidade LGBT. Quando nos acusam de "expor demais" coisas que supostamente deveriam ficar restritas aos nossos quartos, raramente se referem apenas aos nossos atos sexuais. O que está sendo declarado é que determinadas vestimentas, trejeitos, modos de falar, de existir, ou, até mesmo, os atos de andar de mãos dadas com um companheiro do mesmo sexo ou trocar beijos em um restaurante são coisas que não devem fazer parte da esfera pública. Sendo assim, a importância de se manter uma postura radical de falar abertamente sobre práticas dissidentes é fundamentalmente política. "Significa estar consciente de que existe algo insatisfatório e desonesto sobre o modo como o sexo é falado (ou omitido) na vida diária." [nossa tradução] ${ }^{10}$ (CALIFIA, 2000, N.P.)

E é desse modo que o curta de Lacerda se torna político. O “eu” se assume como parte de uma cultura marginalizada e, com isso, assume a responsabilidade descrita por Rascaroli. Ao se posicionar como parte da cultura da pegação, o autor assume para si a posição abjeta que sua prática ocupa na estrutura social, ao mesmo tempo em que reapropria essa abjeção como motivo de orgulho, algo a ser celebrado e proclamado em vídeo. Em certa medida, é o mesmo que faz Califia, por exemplo. Em seus textos acadêmicos fica bastante evidente que seu ativismo é motivado por razões pessoais, já que com frequência ele mesmo descreve experiências suas como praticante do sexo em público, compartilha lembranças de sua descoberta sexual na infância e adolescência, assume sem pudores seus fetiches. Sendo assim, sua produção se converte também em relato em primeira pessoa, colocando na prática de seu trabalho aquilo que defende em suas teorias.

\section{O "eu" é um "nós": a construção de memória coletiva através do relato confessional}

Assim como Corrigan remonta a história do filme-ensaio ao seu passado literário, o mesmo pode ser feito com sua vertente queer. Por ser uma cultura que se formou à margem da produção artística e intelectual hegemônica, muito do nosso legado enquanto comunidade é de ordem oral, transmitido por nós mesmos entre gerações. Sendo assim, os relatos escritos, sejam em formas de diários, autobiografias ou apenas trabalhos que eram muito pessoais para seus autores, são um dos poucos registros oficiais do que era a experiência queer no passado. De Oscar Wilde a Jean Cocteau, muito dos materiais que temos disponíveis para estruturação de uma história queer, dá-se através do gênero confessional literário. Não

\footnotetext{
${ }^{10}$ Do original: "It means being aware that there is something unsatisfying and dishonest about the way sex is talked about (or hidden in daily life)."
}

Periódicus, Salvador, n.11, v. 2, mai-out.2019 - Revista de estudos indisciplinares em gêneros e sexualidades Publicação periódica vinculada ao Núcleo de Pesquisa NuCuS, da Universidade Federal da Bahia - UFBA ISSN: 2358-0844 - Endereço: http://www.portalseer.ufba.br/index.php/revistaperiodicus 
raramente, essas obras dedicam atenção especial à vida sexual de seus autores.

Em 1960, no mesmo Recife onde o jovem Chico Lacerda descobriu seus primeiros desejos perversos, o argentino Tulio Carella explorava as esquinas da cidade em busca de encontros sexuais com outros homens. As anotações feitas sobre o período em seus diários, tornaram-se o livro Orgia: os diários de Tulio Carella, Recife, 1960 (2011). O escritor norte-americano Bruce Benderson, autor da epígrafe desse artigo, publicou em 2006 a obra The romanian: story of an obsession, sua autobiografia relatando o tempo que passou viajando pela Europa acompanhado de um jovem garoto de programa romeno, enquanto os dois viviam diversas aventuras sexuais, mesmo em países onde a homossexualidade era ilegal. Em Close to the knives: a emoir of disintegration (1991), o multiartista David Wojnarowicz reúne ensaios sobre sua vida pessoal que ganharam o status de documento histórico, por formarem um dos principais registros em primeira pessoa durante a crise da AIDS nos Estados Unidos. Nesses três exemplos citados nota-se mais uma vez a relação ostensiva entre a dissidência sexual e o espaço urbano.

O pesquisador cubano José Esteban Muñoz, em seu trabalho sobre o futuro das políticas LGBT em tempos de assimilacionismo, propôs a existência de uma ligação primária entre desejo e política queer. Uma das defesas dessa proposta foi feita justamente através da análise de um livro queer autobigráfico focado na experiência de aventuras sexuais no espaço urbano. Em seu artigo Fantasmas do sexo em público: desejos utópicos, memórias queer ${ }^{11}$, Muñoz parte do conceito de utopia como formulado por Adorno e Bloch para analisar a construção de memória feita em obras artísticas sobre o sexo em público, dentre elas, o livro de memórias You got to burn to shine, de John Giorno (1994). Através dessa análise, Muñoz define a noção daquilo que ele vai chamar de memória utópica queer.

A memória é certamente construída e, o que é mais importante, sempre política. O argumento que eu articulo nesse ensaio postula nossas lembranças e suas narrações ritualizadas - através do filme, do vídeo, da performance, da escrita e da cultura visual - como dotadas de potencialidades materializantes [world-making potentialities]. Mais além, eu sugiro que essas memórias queer da utopia e o desejo que as estruturam, especialmente quando corporalizados em trabalhos que eu identifico como produção cultural mimética-do-sexo-em-público [public-

\footnotetext{
${ }^{11}$ Artigo publicando originalmente como parte do livro Cruising utopia: the then and there of queer futurity (2009). Em 2017, foi traduzido no Brasil por Pablo Assumpção Barros Costa para publicação em edição da revista Periódicus, do Núcleo de Pesquisa e Extensão em Culturas, Gêneros e Sexualidades (NuCuS), vinculado à Universidade Federal da Bahia. Na edição em questão, foi feito justamente um dossiê entitulado Cidades Dissidentes, com diversos textos abordando a relação entre vivências marginais e a cidade. $O$ dossiê pode ser acessado em https://portalseer.ufba.br/index.php/revistaperiodicus/issue/view/1592
}

Periódicus, Salvador, n.11, v. 2, mai-out.2019 - Revista de estudos indisciplinares em gêneros e sexualidades Publicação periódica vinculada ao Núcleo de Pesquisa NuCuS, da Universidade Federal da Bahia - UFBA ISSN: 2358-0844 - Endereço: http://www.portalseer.ufba.br/index.php/revistaperiodicus 
sex-mimetic cultural production], nos ajudam a cavar espaço para uma cidadania sexual existente e viva. (MUÑOZ, 2017, p. 7)

Sendo assim, podemos afirmar que todos esses trabalhos queer em primeira pessoa, sejam eles um livro ou curta-metragem, contribuem para a construção de uma memória queer coletiva. Não só porque essas experiências ressoam e causam identificações entre os/as leitores/as e autores/as, mas porque elas remontam um passado que fornece ferramentas para que pensemos as políticas queer do futuro. Portanto, o falar de si se converte em falar de nós, ao passo em que a experiência pessoal se transforma em memória de uma comunidade. O que poderia ser encarado como um ato de narcisismo (um eco do discurso conservador que vê como puro exibicionismo a exposição do que se entende como questões privadas), é ressignificado através de sua perspectiva histórica. Rascaroli, que, assim como Muñoz, também se utiliza dos escritos de Adorno, associa essa virada ao postulado do filósofo sobre o anacronismo como parte inerente da forma ensaística. Para ela, "o momento do filme-ensaio, então, é politicamente inclinado não apenas porque o ensaio dá voz a demanda por expressão crítica independente, se é utopicamente assim, mas também porque é constitutivamente contra seu tempo.’[nossa tradução] ${ }^{12}$ (RASCAROLI, 2017, p. 5)

$\mathrm{Na}$ introdução do livro The cinema of me: the self and subjectivity in first person documentary, a editora Alisa Lebow (2012), questionando uma acusação implícita no próprio título, reflete sobre o equívoco de se analisar os filmes em primeira pessoa como sendo egocêntricos e autocentrados. Como nota a autora, a estrutura gramátical do termo "primeira pessoa" comporta a possibilidade de ser singular ou plural.

Eu me encontro cada vez mais persuadida pela formulação de Jean Luc Nancy (2000) do singular plural, onde o indivíduo "eu" não existe sozinho, mas sempre "com" o outro, o que é como dizer que ser alguém nunca é singular, mas sempre pressupõe e de fato incorpora o outro. Isso quer dizer que o "eu" é sempre social, sempre relacional de antemão, e quando ele fala, como fazem esses cineastas, na primeira pessoa, talvez pareça com a primeira pessoa do singular "eu" mas, em termos ontológicos, é sempre em efeito, a primeira pessoa do plural "nós". O referencial gramatical nos lembra que a própria linguagem, embora falada por um indivíduo, nunca é completamente nossa própria invenção, nem de ninguém. Apesar do fato de que nós acreditamos que ela expressa nossa individualidade, ela todavia expressa também nossa associação, nossa pluralidade, nossa

${ }^{12}$ Do original: "The moment of the essay film, then, is politically inflected not only because the essay gives voice to the need for independent critical expression, if utopianly so, but also because it is constitutively against its time." 
interrelação com um grupo, uma massa, uma socialidade, se não uma sociedade. Isso é tão verdade sobre a expressão da individualidade e subjetividade em filmes em primeira pessoa quanto na linguagem em si. [nossa tradução] ${ }^{13}$ (LEBOW, 2012, p. 16)

Com essa reflexão, Lebow propõe que o "cinema do eu" que dá título ao livro possa ser entendido como um "cinema do nós". Pelo menos no caso dos filmes queer em primeira pessoa, essa asserção certamente se faz verdadeira, já que essas produções sempre contribuem para a construção queer de mundo (queer world-making), que toma forma nesses relatos "através da performance da memória utópica queer, isto é, de uma utopia que entende que seu tempo estende-se para além de um passado nostálgico (que talvez nunca tenha ocorrido) e de um futuro cuja chegada é continuamente retardada - uma utopia no presente.” (MUÑOZ, 2017, p. 9)

Voltando ao Virgindade, essa perspectiva de um “cinema de nós", articulado por uma construção queer de mundo, agrega novas potências à escolha de Lacerda em não especificar os lugares onde aquelas paisagens se localizam. O narrador traça assim uma cartografia fantasma, que pode ser (e de fato é) transposta para qualquer outra cidade. Ou seja, as lembranças relatadas se associam mais a uma certa condição queer do que aos espaços físicos onde o protagonista as viveu. "A criação de mundo queer, portanto, depende da possibilidade de se mapear um mundo no qual é permitido lançar imagens da utopia, e de incluir essas imagens em qualquer mapa do social.” (MUÑOZ, 2017, p. 11)

Diferente do que acontece na maioria dos ensaios autoretratísticos, em Virgindade o autor nunca se apresenta para o público. Em nenhum momento nós sabemos seu nome ou qualquer informação de quem ele seja. O filme já se inicia com a frase "a primeira vez que eu lembro..." que, embora apresente um sujeito sintático (eu), não permite que nós localizemos o sujeito semântico que a enuncia. O corpo e o rosto do narrador também nunca se materializam. Além de não filmar a si mesmo, Lacerda decide não recorrer ao uso de imagens de arquivo pessoais, como fotografias ou vídeos caseiros, para ilustrar as memórias relatadas pela voz over. É somente durante os créditos finais que as fotografias de sua infância aparecem (Fig. 5), em contraste irônico e debochado com a música

\footnotetext{
${ }^{13}$ Do original: "I find myself increasingly persuaded by Jean Luc Nancy's (2000) formulation of the singular plural, wherein the individual 'I' does not exist alone, but always 'with' another, which is to say being one is never singular but always implies and indeed embodies another. That means the 'I' is always social, always already in relation, and when it speaks, as these filmmakers do, in the first person, it may appear to be in the first person singular 'I' but ontologically speaking, it is always in effect, the first person plural 'we'. The grammatical reference reminds us that language itself, though spoken by an individual, is never entirely our own invention, nor anyone else's. Despite the fact that we believe it to express our individuality, it nonetheless also expresses our commonality, our plurality, our interrelatedness with a group, a mass, a sociality, if not a society. This is as true about the expression of individuality and subjectivity in first person films as it is in language itself."
}

Periódicus, Salvador, n.11, v. 2, mai-out.2019 - Revista de estudos indisciplinares em gêneros e sexualidades Publicação periódica vinculada ao Núcleo de Pesquisa NuCuS, da Universidade Federal da Bahia - UFBA ISSN: 2358-0844 - Endereço: http://www.portalseer.ufba.br/index.php/revistaperiodicus 
Sonhos infantis, da cantora Diana, subvertendo o sentido dos versos "se pudesse, eu voltaria a ser uma criança só pra poder fazer mais do que eu já fiz quando era pequena" (afirmação que acabou sendo usado como sinopse oficial do filme).

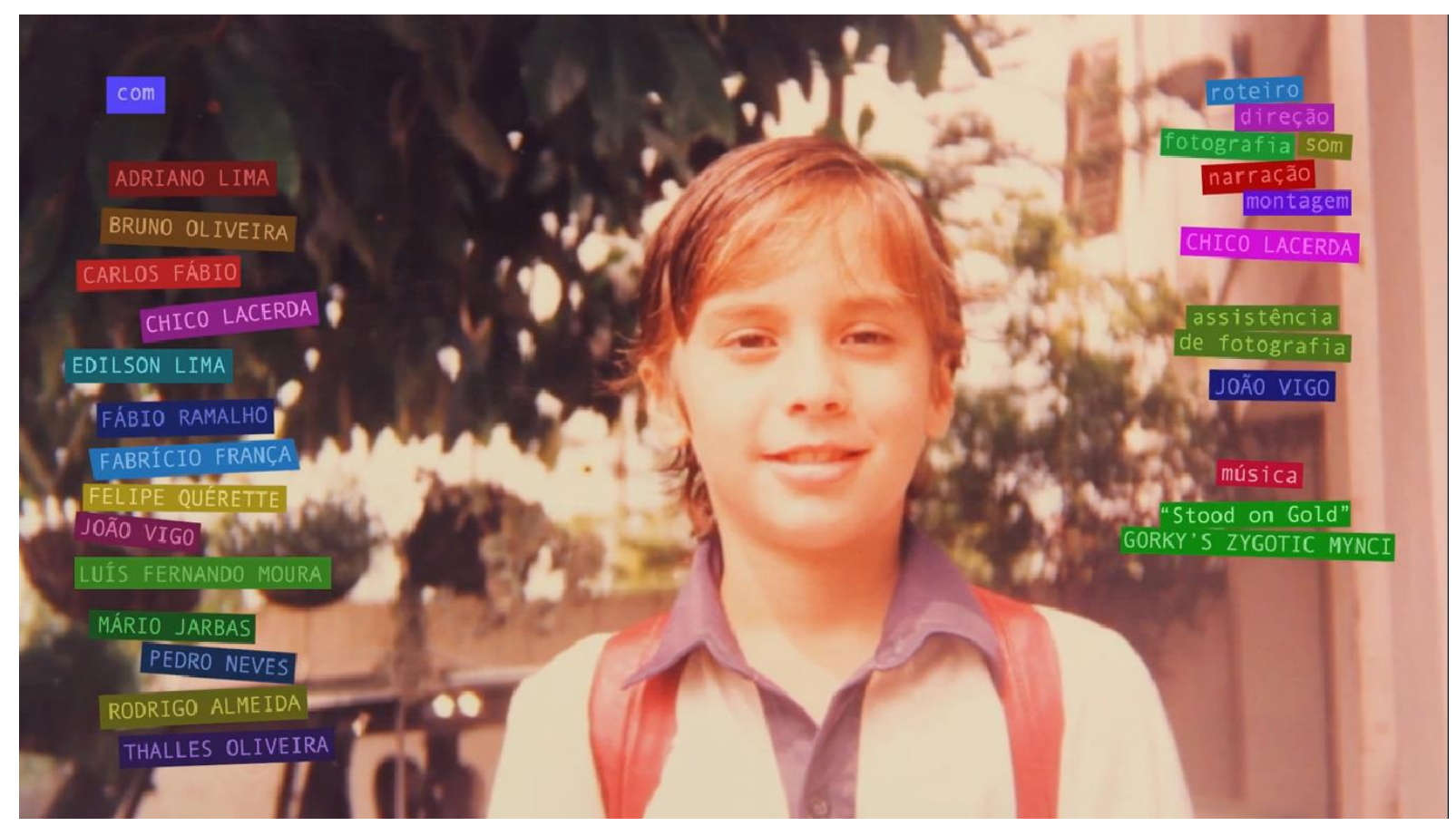

Figura 5 Still de "Virgindade" (Chico Lacerda, 2015)

Ao não especificar sua identidade durante o relato, Lacerda faz com a subjetividade o mesmo que fez com o mapeamento da cidade. Através dessas lembranças de um sujeito sem nome e sem rosto, o espectador queer pode usar a si mesmo para preencher as lacunas. Ao assistir ao filme pela primeira vez, eu mesmo relembrava como passava horas na seção de ficção científica na videolocadora (e não na de terror, como na experiência do narrador) para espiar as prateleiras de filmes pornográficos, ou como eu utilizava as poucas páginas dedicadas a cuecas e sungas dos catálogos de lingerie (e não um "guia de vídeo") para fins de excitação erótica. É através desses ecos entre as narrações ritualizadas e as identificações do espectador que a memória utópica queer se constrói e atualiza.

Há cerca de um ano, um amigo me apresentou um projeto fascinante, que não só dialoga com o trabalho de Lacerda em Virgindade, mas o amplifica em escala global. Criado em meados de 2017 pelx artista canadense Lucas LaRochelle, Queering the map ${ }^{14}$ (algo como "tornar o mapa queer", ou "transviadescendo o mapa") é uma plataforma online em que pessoas queer do mundo inteiro podem

${ }^{14}$ Disponível em: https://www.queeringthemap.com. Acesso em: 28 de janeiro de 2019.

Periódicus, Salvador, n.11, v. 2, mai-out.2019 - Revista de estudos indisciplinares em gêneros e sexualidades Publicação periódica vinculada ao Núcleo de Pesquisa NuCuS, da Universidade Federal da Bahia - UFBA ISSN: 2358-0844 - Endereço: http://www.portalseer.ufba.br/index.php/revistaperiodicus 
marcar a geolocalização de suas próprias memórias e experiências queer (Fig. 6). Segundo a descrição dada no próprio site, “o objetivo do projeto Queering the map é o de documentar coletivamente os espaços que carregam memória queer, de bancos de parques a garagens, para marcar momentos de queerness sempre que eles ocorrerem." [nossa tradução ${ }^{15} \mathrm{O}$ que Lacerda faz com a cidade de Recife pode então ser reproduzido de forma coletiva em todos os lugares.

O que me cativou no projeto de LaRochelle é a visão abrangente do que constitui uma história e memória queer. Ao invés de propor a documentação apenas de eventos legitimados (paradas de orgulho LGBT, casamentos homoafetivos, bairros de cultura queer), a iniciativa não oferece regras do que define um momento queer, convidando as pessoas a compartilharem suas lembranças mais pessoais. "Qualquer coisa entre ativismo direto e uma conversa sobre quais pronomes usar, entre olhares de flerte e longas festas de sexo; tudo é parte do projeto de tornar o espaço queer" [nossa tradução] ${ }^{16}$ Se foi relevante na história de quem narra, foi relevante para memória queer. Atualmente, o projeto conta com mais 17.000 relatos de pessoas queer ao redor do globo. Nos pinos fincados no mapa, é possível encontrar narrativas de saída do armário, de abusos sofridos, de paixões, casamentos e, inclusive, de práticas de sexo em público, criando um mosaico tão rico quanto a cultura queer em si.

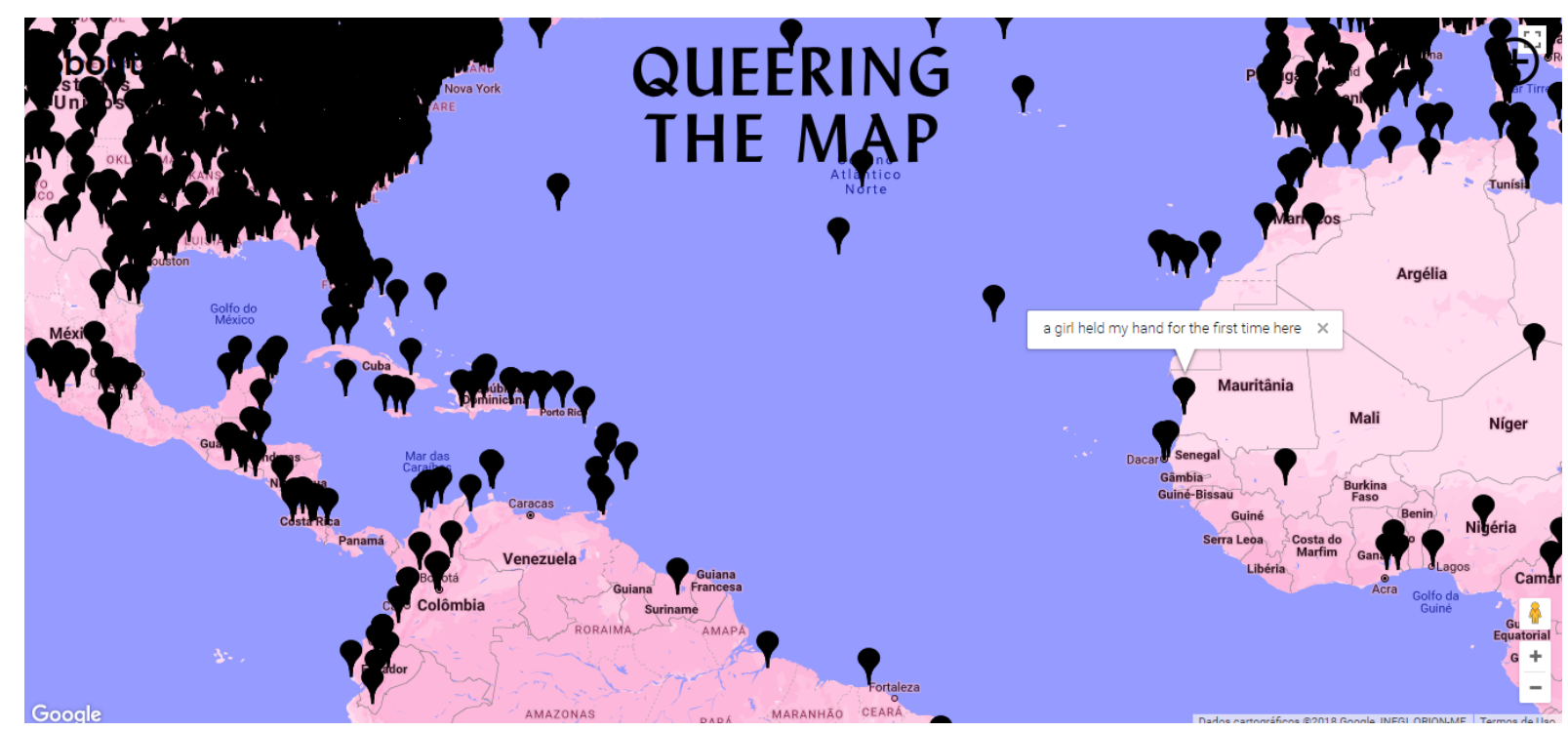

Figura 6 - Projeto online Queering the Map

\footnotetext{
${ }^{15}$ Do original: "The intent of the Queering the Map project is to collectively document the spaces that hold queer memory, from park benches to parking garages, to mark moments of queerness wherever they occur."

${ }^{16}$ Do original: "Anything from direct action activism to a conversation expressing preferred pronouns, from flirtatious glances to weekend long sex parties; all are part of the project of queering space."
}

Periódicus, Salvador, n.11, v. 2, mai-out.2019 - Revista de estudos indisciplinares em gêneros e sexualidades Publicação periódica vinculada ao Núcleo de Pesquisa NuCuS, da Universidade Federal da Bahia - UFBA ISSN: 2358-0844 - Endereço: http://www.portalseer.ufba.br/index.php/revistaperiodicus 
Um desdobramento do projeto online foi a impressão física de um livro composto por 150 capturas de tela do Google Streetview acompanhadas dos textos que narram as memórias compartilhadas do que aconteceu em cada local. Ou seja, utilizando mídias digitais e o processo de criação colaborativo, o livro faz exatamente o mesmo exercício feito por Lacerda através do filmeensaio (comparados em Fig. 7 e 8). Na publicação, também é possível encontrar um ensaio sobre questões políticas relacionadas ao projeto, incluindo citações do livro escrito por Muñoz. Ao pesquisar mais sobre LaRochelle, descobri que em seu site profissional ${ }^{17}$ a pessoa se assume como "grande entusiasta da necessidade de se imaginar utopia, sua prática debate os problemas do 'aqui e agora' enquanto um meio de se engajar com o futuro imaginário." [nossa tradução ${ }^{18}$, indicando uma filiação direta aos postulados do pesquisador cubano, que provavelmente inspirou o que o projeto de Queering the map compreende como memória. O legado de Muñoz, falecido em 2013, germina no futuro imaginário que o mesmo propôs.

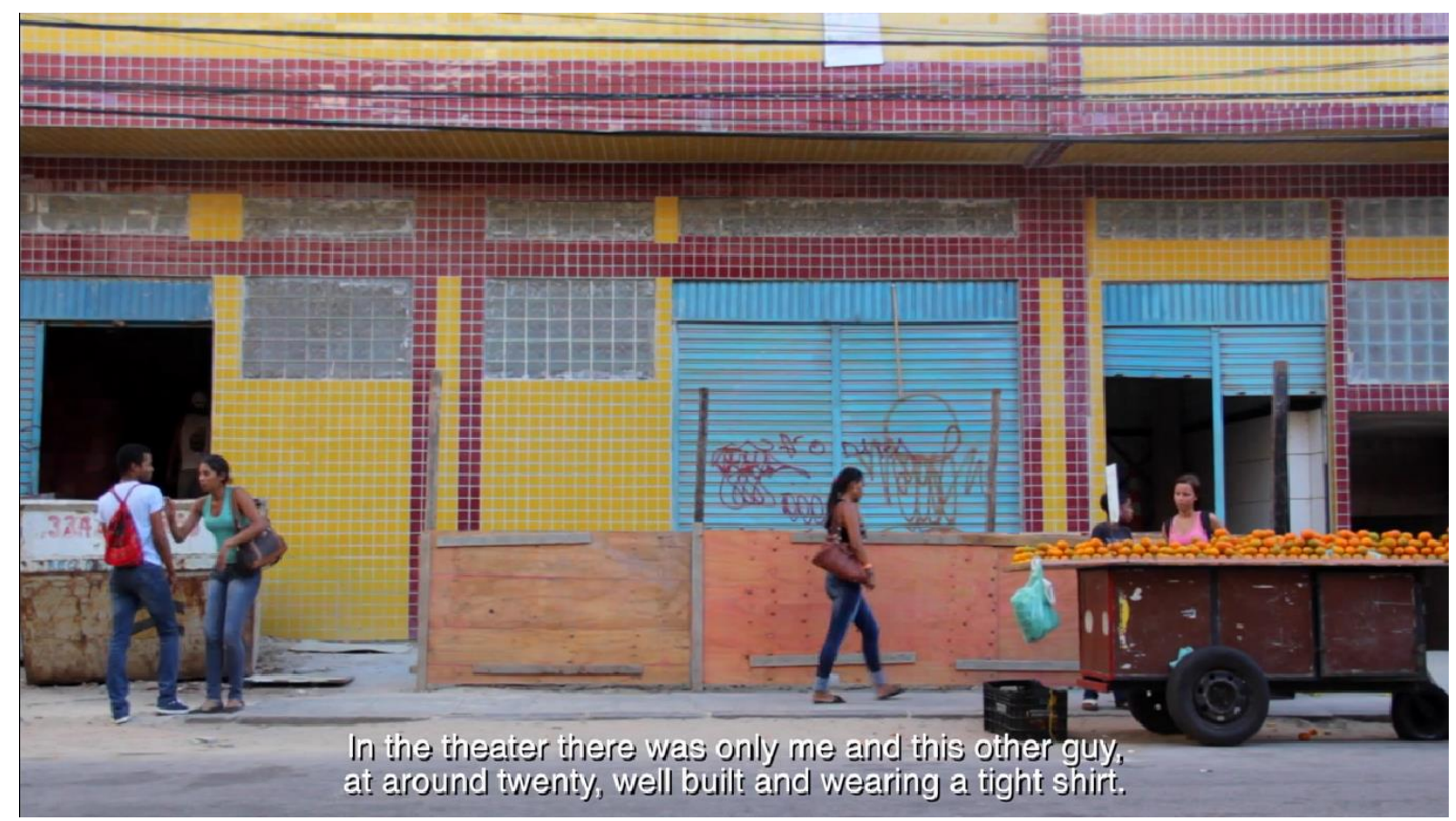

Figura 7 - Still de "Virgindade" (Chico Lacerda, 2015)

\footnotetext{
${ }^{17}$ Disponível em: http://lucaslarochelle.com/info/. Acesso em: 28 de janeiro de 2019.

${ }^{18}$ Do original: "A firm believer in the necessity of imagining utopia, their practice contends with the problems of the 'here and now' as a means of engaging with the future imaginary."
} 


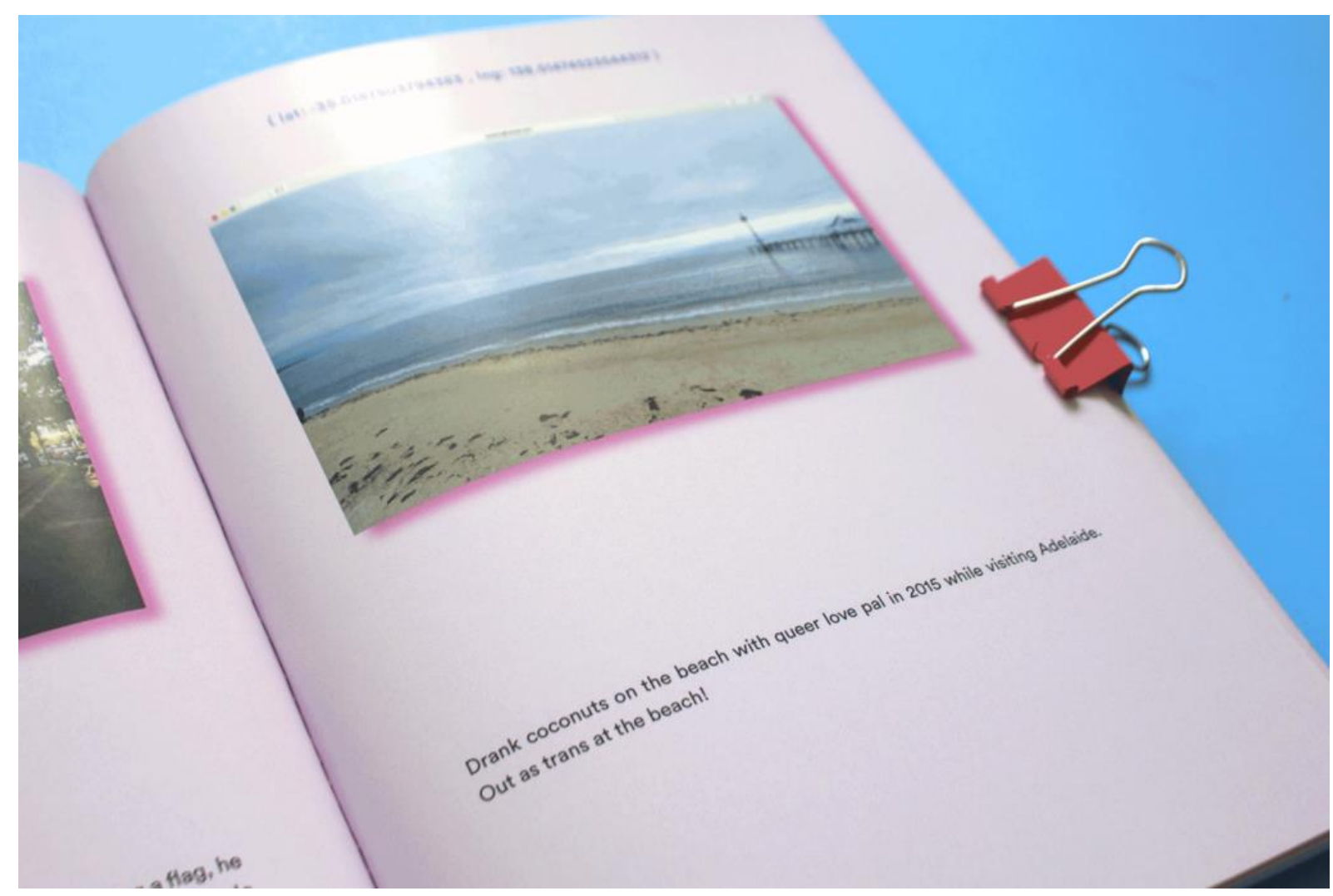

Figura 8 - Livro impresso do projeto Queering the map. Fonte: http://lucaslarochelle.com/queeringthe-map-book

\section{Conclusão}

Embora, em uma primeira análise, o filme em primeira pessoa possa parecer um domínio necessariamente narcisista e egocêntrico, voltado a questões que não dizem respeito a mais ninguém além de seu autor, nota-se um consenso, ao menos entre os/as três autores/as aqui utilizados/as (Laura Rascaroli, Alisa Lebow e Timothy Corrigan), em reconhecer esse tipo de cinema como detentor de grande potencial político. Através da análise do filme Virgindade, podemos observar como o compartilhamento de lembranças, desejos e confissões tão intímas podem se converter em memória coletiva. Certifica-se, com facilidade, o postulado de Lebow sobre a natureza plural do gênero em primeira pessoa. Embora seja inviável comprovar se isso se faz verdade em todos os casos, é seguro afirmar que dificilmente um relato pessoal, por mais autocentrado que seja, surja desprovido de qualquer valor político-social, já que é necessariamente anacrônico e, como aponta Rascaroli, possui um momento que o coloca contra seu tempo, ganhando valor histórico. Ou, como coloca a autora em um dos capítulos do livro Cinema of me: the self and subjectivity in first person documentary, "autoretratos costumam ser simultaneamente declarações sobre a personalidade do artista e de seu status na 
sociedade.” [nossa tradução] ${ }^{19}$ (RASCAROLI, 2012, p. 74)

Essa relação fica explícita na análise de Virgindade e das demais obras aqui citadas, em qualquer mídia que seja, já que todas servem como testemunhos da condição queer em nossa sociedade, contribuindo para a atualização da memória utópica queer formulada por Muñoz. Seja a autobiografia literária de um escritor argentino, o filme-ensaio de um cineasta brasileiro ou o relato online de uma pessoa trans canadense, todos esses trabalhos contribuem para a formatação de uma história queer, diretamente associada a espaços físicos, e que servem como um modo de manter viva a relação entre desejo e política na experiência de pessoas queer.

Em um dos meus depoimentos favoritos em Queering the map, um homem relembra o dia em que, ainda criança, conheceu um adolescente gay que o ajudou no seu processo de aceitação. No final do texto, ele diz: "prestem atenção nos jovens queers por aí, eles podem precisar da nossa ajuda." (Fig. 9) Para mim, o principal eco dos trabalhos de Lacerda, Califia, LaRochelle, Muñoz, Giorno, Benderson e tantos/as outros/as, é o de, anacronicamente, oferecer essa ajuda, alargando cada vez mais o espaço cavado para a sonhada cidadania sexual existente e viva.

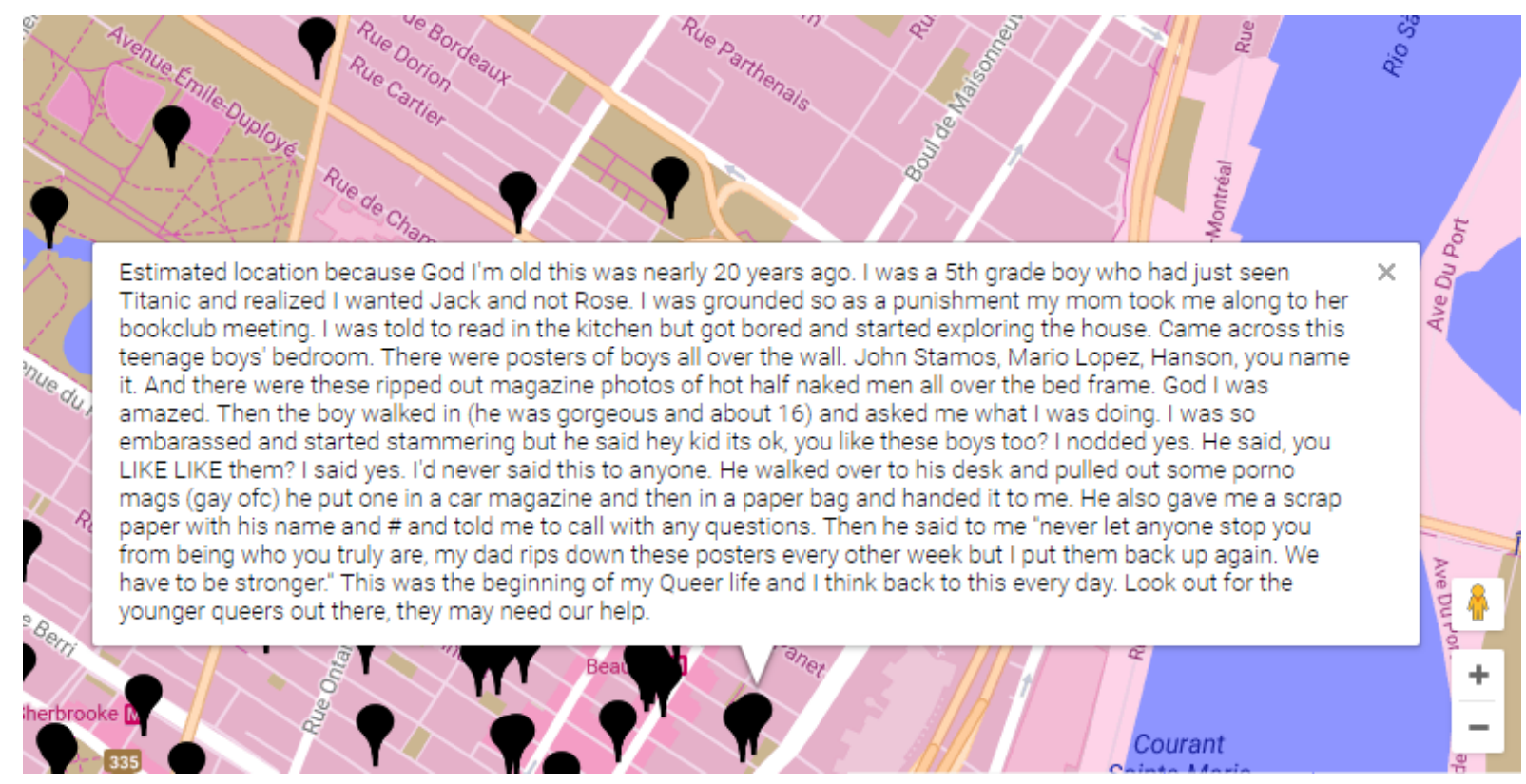

Figura 9 - Relato disponivel na plataforma online Queering the map

19 Do original: "Self-portraits are usually statements simultaneously about the artist's personality and her status in society."

Periódicus, Salvador, n.11, v. 2, mai-out.2019 - Revista de estudos indisciplinares em gêneros e sexualidades Publicação periódica vinculada ao Núcleo de Pesquisa NuCuS, da Universidade Federal da Bahia - UFBA ISSN: 2358-0844 - Endereço: http://www.portalseer.ufba.br/index.php/revistaperiodicus 


\section{Referências}

CALIFIA, Patrick. Public sex: The culture of radical sex. Cleis Press, 2000. Não paginado.

CORRIGAN, Timothy. O filme-ensaio: desde Montaigne e depois de Marker. Campinas: Papirus, 2015.

LEBOW, Alisa (Ed.) The cinema of me: the self and subjectivity in first person documentary. Columbia University Press, 2012.

MUÑOZ, José Esteban. Fantasmas do sexo em público: Desejos utópicos, memórias queer. Revista Periódicus, v. 1, n. 8, p. 04-19, nov. 2017 - abr. 2018.

RASCAROLI, Laura. How the essay film thinks. Oxford University Press, 2017.

RICH, B. Ruby. New queer cinema: the director's cut. Duke University Press, 2013. 